\title{
Associação entre a fibrose cística e o Polimorfismo rs2609255 no gene FAM13A.
}

\author{
João Vitor Vaz Leitão*, Carmen S. Bertuzzo.
}

\section{Resumo}

A Fibrose Cística(FC) é uma doença monogênica autossômica recessiva, progressiva e de diversas manifestações clínicas. A FC é causada por mutações no gene CFTR(Cystic Fibrosis Transmembrane Regulator) que codifica a proteína CFTR, i.e. canal iônico localizados na membrana apical de células epiteliais responsáveis pelo transporte ativo do cloro. Existem diversas mutações do gene CFTR, sendo que pacientes com genótipos iguais da doença podem apresentar fenótipos distintos. Existem genes diferentes do CFTR que foram associados a alteração do quadro clínico dos pacientes. Tais genes foram chamados de modificadores. O polimorfismo rs2609255 foi associado a quadros de fibrose pulmonar e, portanto seria bom candidato para modular a expressão clínica da FC. Para isso. Foram investigados o genótipo do polimorfismo rs2609255 em 100 pacientes fibrocísticos com a técnica de Real-Time PCR.

\section{Palavras-chave:}

Fibrose Cística, FAM13A, rs2609255.

\section{Introdução}

Fibrose cística (FC) (OMIM: 219700) é uma doença monogênica autossômica recessiva frequente na população euro-descendente [1]. A FC é decorrente da ausência ou codificação alterada (qualitativa/quantitativa) da proteína CFTR(Cystic fibrosis transmembrane conductance regulator) por mutações no gene CFTR e está associada a obstrução crônica da região luminal e recorrentes quadros inflamatórios por excesso de muco hiperviscoso oriundo da diminuição no transporte de íons cloreto no epitélio exócrino[2,3]. As manifestações clínicas permeiam com variedade de sintomas respiratórios, gastrointestinais (intestino, fígado e pâncreas), de sistema reprodutor e glândulas sudoríparas $[2,4]$, sendo as manifestações pulmonares mais desafiadoras pela variação, evolução e gravidade [5] e principal causa de morbimortalidade pela doença [6].

Além das mutações no gene CFTR, que possuem ação bem definida e estão diretamente relacionadas à manifestação da FC, variantes em outros genes devem ser consideradas pela possibilidade de envolvimento na via de resposta ou tratamento da doença, bem como, por possibilitar terapias secundárias, melhor entendimento da doença e de sua variabilidade clínica, além de poderem ser marcadores de evolução clínica do paciente, após a identificação de associação com a gravidade da doença[7].

O gene FAM13A (Family with sequence similarity 13 member A)encontra-se na região $4 q 22.1$, é formado por 31 exons e tem sido fortemente associado à doença pulmonar obstrutiva crônica (DPOC) [8]. O polimorfismo Rs2609255, é uma troca de $\mathrm{T}$ (timina) para G (guanina) em região intrônica do gene. Recentemente foi associado fortemente com fibrose pulmonar idiopática [9]. Portanto, seria um bom candidato a gene modulador da gravidade clínica da Fibrose Cística.

\section{Resultados e Discussão}

Foram analisadas 100 amostras, e dessas, 20 não se encontraram aptas a utilização na pesquisa. Das 80 amostras restantes, 3 são homozigóticas para o polimorfismo rs2609255(mutantes), 26 são heterozigóticas para esse polimorfismo e as demais são homozigóticas selvagens(normais). Demais resultados e discussão estão em produção.

\section{Conclusão a ser feita.}

Conclusão

\footnotetext{
${ }^{1}$ Geborek A, Hjelte L. Association between genotype and pulmonary phenotype in cystic fibrosis patients with severe mutations. J Cyst Fibros. 2011; 10(3):187-92.

${ }^{2}$ Cutting GR. Modifier genes in Mendelian disorders: the example of cystic fibrosis. Ann N Y Acad Sci. 2010;1214:57-69.

${ }^{3}$ Lubamba B, Dhooge B, Noel S, Leal T. Cystic fibrosis: Insight into CFTR pathophysiology and pharmacotherapy. Clin Biochem. 2012; 45(15):1132-44. ${ }^{4}$ Tsui LC, Buchwald M, Barker D, Braman JC, Knowlton R, Schumm JW. Cystic fibrosis locus defined by a genetically linked polymorphic DNA marker. Science. 1985; 230(4729).

${ }^{5}$ Braun AT, Farrell PM, Ferec C, Audrezet MP, Laxova A, Li Z et al. Cystic fibrosis mutations and genotype-pulmonary phenotype analysis. J Cyst Fibros. 2006; 5(1):33-41.

${ }^{6}$ Ramsey BW, Davies J, McElvaney NG, Tullis E, Bell SC, Dřevínek P et al. A CFTR Potentiator in Patients with Cystic Fibrosis and the G551D Mutation. $N$ Engl J Med. 2011; 365(18):1663-72.

${ }^{7}$ Boyle MP. Strategies for Identifying Modifier Genes in Cystic Fibrosis. Proc Am Thorac Soc. 2007; 4(1):52-7.

${ }^{8}$ Eisenhut F, Heim L, Trump S, Mittler S, Sopel N, Andreev K, Ferrazzi F, Ekici AB, Rieker R, Springel R, Assmann VL, Lechmann M, Koch S, Engelhardt M, Warnecke C, Trufa DI, Sirbu H, Hartmann A, Finotto S. FAM13A is associated with non-small cell lung cancer (NSCLC) progression and controls tumor cell proliferation and survival.Oncoimmunology. 2016 6(1):e1256526.

${ }^{9}$ Hirano C, Ohshimo S, Horimasu Y, Iwamoto H, Fujitaka K, Hamada H, Hattori N, Shime N, Bonella F, Guzman J, Costabel U, Kohno N. FAM13A polymorphism as a prognostic factor in patients with idiopathic pulmonary fibrosis. Respir Med. 2017 Feb;123:105-10.
} 